\title{
1 Molecular phylogeny of the Achatinoidea (Mollusca: Gastropoda)
}

4 Ian Kendrich Fontanilla ${ }^{\mathrm{a}, \mathrm{c}}$, Fred Naggs ${ }^{\mathrm{b}}$, Christopher Mark Wade ${ }^{\mathrm{a}, *}$

$5 \quad{ }^{a}$ School of Life Sciences, University of Nottingham, University Park, Nottingham, United

6 Kingdom

$7 \quad{ }^{b}$ Life Sciences Department, Natural History Museum, London, United Kingdom

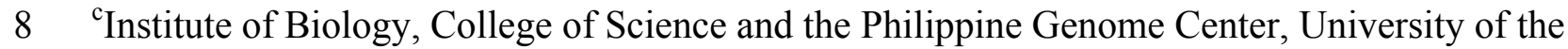

9 Philippines, Diliman, Quezon City, Philippines ${ }^{1}$

10

$11 *$ corresponding author (Chris.Wade@nottingham.ac.uk)

$12 \quad{ }^{1}$ Present address of IKF 


\section{Abstract}

14 This study presents a multi-gene phylogenetic analysis of the Achatinoidea and provides an

15 initial basis for a taxonomic re-evaluation of family level groups within the superfamily. A total

16 of 5028 nucleotides from the nuclear rRNA, actin and histone 3 genes and the $1^{\text {st }}$ and $2^{\text {nd }}$ codon

17 positions of the mitochondrial cytochrome c oxidase subunit I gene were sequenced from 24

18 species, representing six currently recognised families. Results from maximum likelihood,

19 neighbour joining, maximum parsimony and Bayesian inference trees revealed that, of currently

20 recognised families, only the Achatinidae are monophyletic. For the Ferussaciidae, Ferussacia

21 folliculus fell separately to Cecilioides gokweanus and formed a sister taxon to the rest of the

22 Achatinoidea. For the Coeliaxidae, Coeliaxis blandii and Pyrgina umbilicata did not group

23 together. The Subulinidae was not resolved, with some subulinids clustering with the

24 Coeliaxidae and Thyrophorellidae. Three subfamilies currently included within the Subulinidae

25 based on current taxonomy likewise did not form monophyletic groups.

27 Keywords: Achatinoidea, rRNA, actin, histone 3, COI 


\section{Introduction}

The Achatinoidea are a large group of terrestrial land snails of the informal group

31 Sigmurethra (Vaught 1989; Bouchet and Rocroi, 2005) in over 100 genera and include the Giant

32 African Snails. Generic placements within the Achatinoidea have varied considerably (Thiele,

33 1931; Zilch, 1959; Vaught, 1989; Schileyko, 1999, 2001; see also Supplementary Data 1).

34 Taxonomic placements of family level categories have also varied enormously, and there has

35 been little consensus. Solem's (1978) Achatinacea (=Achatinoidea) included the Achatinidae,

36 Ferussaciidae, Megaspiridae, Spiraxidae and Subulinidae. Nordsieck (1986) recognized ten

37 superfamilies within what he classified as the Achatinid Sigmurethra: the Partuloidea,

38 Orthalicodea, Achatinoidea, Aillyoidea, Oleacinoidea, Streptaxoidea, Acavoidea, Rhytidoidea,

39 Plectopylidoidea and the Punctoidea. Within the Achatinoidea, he recognised five families: the

40 Achatinidae, Ferussaciidae, Subulinidae, Coeliaxidae and Thyrophorellidae. Tillier (1989)

41 classified land snails under the superfamily Achatinoidea based on the presence of a closed

42 ureter in the excretory system, symmetrical cerebro-pedal connectives, a short commissure, and

43 contiguous left parietal and visceral ganglia in the nervous system. In addition to the

44 Ferussaciidae, Subulinidae, Achatinidae, and the Streptaxidae, Tillier included the Succineidae

45 within the Achatinoidea. Vaught (1989) followed Nordsieck (1986) in recognising the

46 Ferussaciidae, Subulinidae, Achatinidae, Coeliaxidae and Thyrophorellidae within the

47 Achatinoidea but also provided a full hierarchy of subfamily groups and genera. Schileyko

48 (1999) placed only the Achatinidae in the Achatinoidea. Based on shell characters and, where

49 available, his interpretation of features of the reproductive tract proximal to the genital orifice,

50 Schileyko (1999) introduced substantial changes in his classification of the Subulinidae with nine

51 subfamilies: Subulininae, Petriolinae, Rishetiinae, Rumininae, Opeatinae, Obeliscinae, 
52 Perrieriinae, Tristaniinae, and Coeliaxinae (=Coeliaxidae according to Nordsieck, 1986). He also

53 recognised four families within his Subulinoidea: Micractaeonidae, Ferrussaciidae (=

54 Ferussaciidae, see Bouchet and Rocroi, 2005), in which he included the Ferrussaciinae

55 (=Ferussaciinae), and Cryptazecinae.

56 Molecular phylogenetic studies (Wade et al., 2001, 2006) based on the nuclear ribosomal

57 (r)RNA gene cluster (parts of the 5.8S and LSU genes) revealed a principal division of the

58 Stylommatophora into two major clades. The 'achatinoid' clade comprises the superfamilies

59 Streptaxoidea, represented by the Streptaxidae, and the Achatinoidea, represented by the

60 Achatinidae, Coeliaxidae, Ferussaciidae, Subulinidae and Thyrophorellidae as adopted by

61 Vaught (1989) and followed by Wade et al. (2006). A study by Sutcharit et al. (2010) now also

62 includes the Diapheridae in the Streptaxoidea. All other stylommatophoran families fall within

63 the 'non-achatinoid' clade. The Spiraxidae (represented by Euglandina) and Succineidae

64 (represented by Succinea) fell within the 'non-achatinoid' clade, thus contradicting Solem (1978)

65 for his inclusion of the Spiraxidae and Tillier (1989) for his inclusion of the Oleacinidae

66 (Spiraxidae and Testacellidae) and the Succineidae. For the purpose of discussion in the current

67 study, we provisionally adopt an Achatinoidea that largely resembles Nordsieck's family level

68 arrangement as adopted by Vaught, comprising the Achatinidae, Coeliaxidae, Ferussaciidae,

69 Subulinidae and Thyrophorellidae (see Supplementary Data 1).

70 To date, molecular phylogenetic studies of the Achatinoidea have been restricted to the

71 use of a single genetic marker, part of the nuclear rRNA gene cluster (Wade et al., 2001, 2006).

72 To examine relationships among the Achatinoidea, we utilise a four-fold expanded segment of

73 the Wade et al. rRNA gene cluster as well as three other markers, the nuclear actin and histone 3

74 genes and the mitochondrial $\mathrm{CO} 1$ gene. We also expand our taxon coverage of the Achatinoidea 
75 to include 24 species from all of Vaught's five families. Specifically, this study aimed to: (1)

76 validate the monophyly of the families within the superfamily Achatinoidea based on available

77 taxa; and (2) to evaluate five subfamilies within the Subulinidae.

\section{Materials and methods}

Twenty-four taxa from five achatinoid families (Achatinidae, Coeliaxidae, Ferussaciidae,

81 Subulinidae and Thyrophorellidae) and three streptaxid outgroup taxa were used to evaluate the phylogeny of the Achatinoidea (see Supplementary Material Data 1 and 2). Four subulinid

83 subfamilies recognised from Schileyko's (1999) classification (Petriolinae, Rishetiinae,

84 Rumininae and Subulininae) and the Glessulinae recognized from Vaught (1989) were also represented. Thirteen taxa were entirely new to this study while the remaining 14 taxa were used by Wade et al. (2006).

For all new specimens, tissue slices (approximately eight $\mathrm{mm}^{3}$ ) from the foot muscle of the snail were obtained and the DNA was extracted using a CTAB DNA extraction method

89 (Goodacre \& Wade, 2001; see also Supplementary Material under section 'DNA extraction'). Amplification of fragments of the ribosomal (r) RNA gene cluster, actin, histone 3, and

91 the cytochrome $\mathrm{c}$ oxidase subunit I (COI) genes were carried out following the protocol under

92 'PCR amplification' in the Supplementary Material and using the primers listed in

93 Supplementary Data 3 and 4. For all fragments, both sense and anti-sense strands were

94 sequenced directly using an Applied Biosystems 3730 DNA sequencer and BigDye version 3.1

95 termination cycle sequencing chemistry.

96 Processing of sequences, saturation tests, phylogenetic analyses using maximum

97 likelihood (ML), neighbour joining (NJ), maximum parsimony (MP) and Bayesian inference 
98 (BI), and partition homogeneity tests are described in the Supplementary Material under

99 'Sequence processing and phylogenetic analyses.'

100 Nucleotide sequences generated in this study are deposited in GenBank under accession

101 numbers MF415320-MF415391 and MF444863-MF444894.

102

103 3. Results

Phylogenetic trees of the Achatinoidea were built using a concatenated dataset

105 comprising 5028 unambiguously aligned nucleotide sites from the rRNA (3435 nucleotides),

106 actin (861 nucleotides), histone 3 (328 nucleotides), and $1^{\text {st }}$ and $2^{\text {nd }}$ codon positions of the

107 cytochrome c oxidase subunit I gene (404 nucleotides) as well as individually for each gene. The

$1083^{\text {rd }}$ codon position of the COI gene was shown to be oversaturated (Iss $=0.7387$; value

109 significantly higher than Iss.c $=0.6761$ for a completely symmetrical tree and Iss.c $=0.3992$ for an

110 extremely asymmetrical tree; Xia et al., 2003) and excluded from analyses. The following taxa

111 had missing DNA sequence data: Cecilioides gokweanus (histone 3 and COI), Paropeas

112 achatinaceum (histone 3), Riebeckia sp. (histone 3), Subulina vitrea (histone 3), Gonaxis

113 quadrilateralis (histone 3 and COI) and Gonospira sp. (histone 3 and COI). These taxa were still

114 included in the combined dataset but with missing data represented as gaps. A partition

115 homogeneity test of the four regions revealed that these could be concatenated into a single

116 dataset at $P=0.001$ (Cuningham, 1997). For the model-based tree-construction methods (ML, BI

117 and NJ), LRT identified the GTR $+\Gamma$ as the optimal model. For the non-model based MP method,

118 a total of 533 parsimony-informative sites were used. 


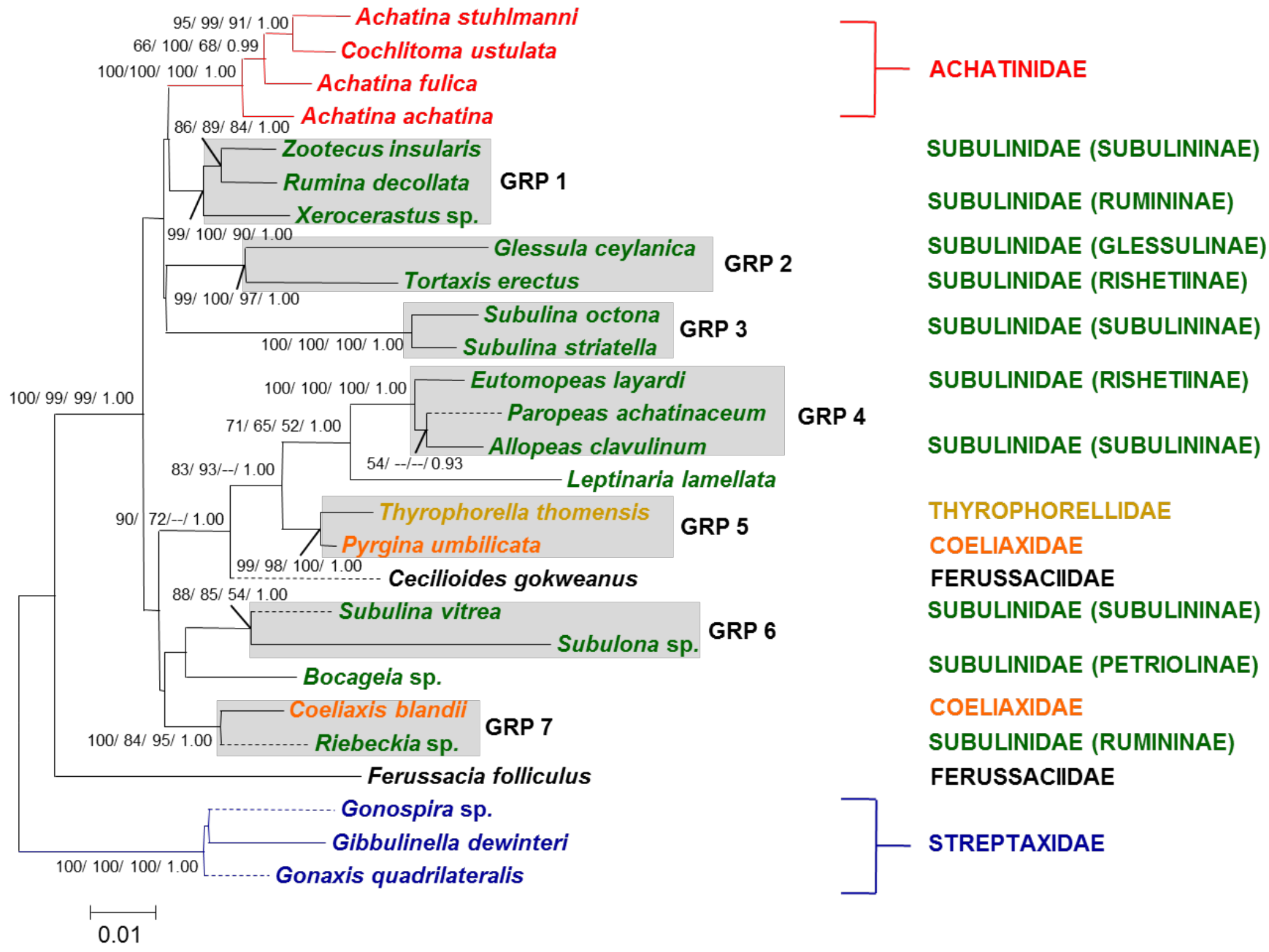

122 Figure 1. Maximum likelihood phylogenetic tree of the Achatinoidea based on a concatenated 123 sequence of 5028 nucleotides from the combined dataset of the rRNA cluster, actin and $\mathrm{H} 3$ genes 124 and the $1^{\text {st }}$ and $2^{\text {nd }}$ codon positions of the COI. For the model-based tree construction methods 125 (ML, NJ and BI), the optimal model used was GTR $+\Gamma$. The phylogeny is rooted on the streptaxids Gibbulinella dewinteri, Gonaxis quadrileteralis and Gonospira sp. Values on the nodes represent bootstrap support (1000 replicates) for ML, NJ and MP, and posterior probabilities (based on the last 1000 trees) for BI, respectively. Bootstrap support less than 50\% and posterior probabilities less than 0.7 are not shown. For BI, the optimized number of generations to explore the tree space was 2,000,000 while the optimized heating temperature was 0.125 . The scale bar represents 1 substitutional change per 100 nucleotides. Clades in grey (GRPS 1-7) refer to groups discussed in the text. Branches for taxa with missing data are marked with dashes. 
137 support for all four tree methods (100\% ML, 100\% NJ, 100\% MP bootstraps; PP=1.0 BI). The

138 other achatinoid families were not recovered in the tree, but seven groupings with strong support

139 were resolved. Group 1 incorporated the subulinids Xerocerastus sp., Rumina decollata and

140 Zootecus insularis (99\% ML, 100\% NJ, 90\% MP bootstraps; PP=1.0 BI). Group 2 contained the

141 subulinid Tortaxis erectus and the glessulinid Glessula ceylanica (99\% ML, 100\% NJ, 97\% MP

142 bootstraps; PP=1.0 BI). Group 3 consisted of two species of Subulina, S. octona and S. striatella

143 with full support (100\% ML, 100\% NJ, 100\% MP bootstraps; PP=1.0 BI). Group 4 included the

144 subulinids Eutomopeas layardi, Paropeas achatinaceum and Allopeas clavulinun with full

145 support (100\% ML, 100\% NJ, 100\% MP bootstraps; PP=1.0 BI). Additionally, the subulinid

146 Leptinaria lamellata clusters with group 4 with all four tree methods, though support is

147 equivocal (71\% ML, 65\% NJ, 52\% MP bootstraps; PP=1.0 BI). Group 5 clustered the

148 thyrophorellid Thyrophorella thomensis and the coeliaxid Pyrgina umbilicata (99\% ML, 98\%

$149 \mathrm{NJ}, 100 \% \mathrm{MP}$ bootstraps; PP=1.0 BI). Group 6 incorporated the subulinids Subulina vitrea and

150 Subulona sp. (88\% ML, 85\% NJ, 54\% MP bootstraps; PP=1.0 BI). Group 7 contained the

151 coeliaxid Coeliaxis blandii and the subulinid Riebeckia sp. (100\% ML, 84\% NJ, 95\% MP

152 bootstraps; PP=1.0 BI). Finally, the ferussacid Cecilioides gokweanus falls as the sister taxon to

153 groups 4 and $5(90 \% \mathrm{ML}$ and $72 \% \mathrm{NJ}$ bootstraps; $\mathrm{PP}=1.0 \mathrm{BI})$ and separately to the other

154 ferussacid in the study, Ferussacia folliculus, which fell at the base of the Achatinoidea.

A separate maximum likelihood phylogeny of the Achatinoidea but excluding taxa with

157 missing DNA sequence data was constructed. Its topology proved to be very similar to the

158 phylogeny of the Achatinoidea with all taxa included (see Supplementary Data 5). Phylogenies

159 based on each individual gene were also conducted and are shown in Supplementary Data 6. 
Seven monophyletic groups proposed in previous classifications (see Supplementary

161 Data 1) that were not recovered in the phylogenetic trees were subjected to hypothesis testing

162 using the Shimodaira-Hasegawa (SH, 1999) test. These groups were the Coeliaxidae,

163 Ferussaciidae, and Subulinidae; within the Subulinidae were the subfamilies Petriolinae,

164 Rishetiinae, Rumininae and the Subulininae. Except for the Petriolinae, monophyly of all the 165 groups was rejected.

167 4. Discussion

Wade et al. (2001) provided the first molecular evidence for the monophyly of the

169 Achatinidae based on the partial fragment of the rRNA cluster. Further molecular evidence for 170 achatinid monophyly is given in this study using an expanded rRNA dataset and the inclusion of

171 three other genes for four taxa. The next logical step is to carry out a comprehensive survey of

172 taxa within the Achatinidae to determine the extent of their monophyly and provide a molecular 173 basis of their inter-relationships.

174 This study included two representatives from the Ferussaciidae, Ferussacia folliculus and

175 Cecilioides gokweanus. The two taxa did not cluster together as expected, and the early

176 divergence of $F$. folliculus from the rest of the Achatinoidea was strongly supported.

177 Furthermore, the SH test conclusively rejected the monophyly of the Ferussaciidae. Cecilioides 178 gokweanus has only been described conchologically; its internal anatomy has not been studied, 179 although that of the type species, Cecilioides acicula, is available. Cecilioides acicula, like 180 Ferussacia folliculus, exhibits characteristics unique to Ferussaciidae such as the short but 181 transversely elongated kidney (Watson, 1928; Tillier, 1989). However, the kidney of C. acicula 182 is broader and curves gradually forward as it approaches the rectum whereas that of $F$. folliculus 
183 bends abruptly where it meets the rectum. Furthermore, C. acicula possesses an indistinct penis 184 papilla (Watson, 1928). There is therefore no compelling evidence from morphological data to 185 show that the Ferussaciidae is monophyletic, and the molecular data from this study support their 186 polyphyly.

The Subulinidae (represented by 15 taxa) are polyphyletic, with members of the

188 Coeliaxidae and Thyrophorellidae falling among the subulinids and with subulinid monophyly 189 being significantly rejected by the SH test. The phylogenies also revealed that the Coeliaxidae, 190 which are regarded as a subfamily, Coeliaxinae, under the Subulinidae by Schileyko (1999), are 191 likewise not monophyletic, as Coeliaxis blandii and Pyrgina umbilicata did not cluster together. 192 Coeliaxidae monophyly was also significantly rejected by the SH test.

193 The polyphyly of the subulinids is not surprising considering several taxa have not been 194 described anatomically and are grouped together based only on their shell morphology and 195 geographic distribution (Schileyko, 1999). However, some fascinating groupings have emerged. 196 For instance, Xerocerastus sp., Rumina decollata and Zootecus insularis formed one 197 group. Xerocerastus has a sub-Saharan distribution; $R$. decollata has been widely distributed 198 through human agency from the Americas to Australia but its natural range is circum199 Mediterrenean; Z. insularis is present from the Cape Verde Islands through North Africa, Arabia, 200 India and Burma (Pilsbry, 1906-1907). This grouping is also in agreement with Zilch's (1959201 1960) premise that Zootecus should be placed together with the Rumininae. Most descriptions of 202 Xerocerastus species are limited to the shell (Van Bruggen, 1970; Schileyko, 1999), but 203 according to Schileyko (1999), both $R$. decollata and Z. insularis have a very short to nearly 204 absent oviduct. Xerocerastus should be evaluated anatomically to determine if it shares any 205 morphological features with $R$. decollata and Z. insularis. 
The subulinids Allopeas clavulinum (Subulininae), which has a cosmopolitan

207 synanthropic distribution (Schileyko, 1999), and Paropeas achatinaceum (Subulininae), which is

208 distributed in the Indo-Pacific region (Naggs, 1994), clustered with another subulinid,

209 Eutomopeas layardi (Rishetiinae), which has a restricted distribution, being found in Sri Lanka,

210 Comoros and Lombok (Schileyko, 1999). Both Allopeas and Eutomopeas share similar shell

211 characteristics, including shape, size and translucence, which they also share with many

212 subulinids, whereas Paropeas tends to be more turrited in shape. The reproductive anatomy of $A$.

213 clavulinum and $P$. achatinaceum have been described, so the logical next step is to examine how

214 the internal structures of E. layardi compare with the other two and if these structures are also

215 congruent with molecular data. If so, then the shell characteristics used to distinguish the two

216 taxa into separate subfamilies and even genera need to be revisited.

217 Pyrgina umbilicata (Coeliaxidae) formed a group with Thyrophorella thomensis

218 (Thyrophorellidae). The position of Thyrophorellidae has been speculatively placed in a wide 219 range of systematic positions (Thiele, 1931; Zilch, 1959: Solem, 1978; Tillier, 1989; Schileyko, 220 2001) without consensus. Nordsieck (1986) was the first to suggest provisional placement of the 221 Thyrophorellidae in the Achatinoidea, although he did not provide a justification. In Wade et al's 222 (2006) molecular phylogenetic tree of the Stylommatophora, Thyrophorella clustered with 223 Pyrgina as achatinoid sister taxa. Here the Thyrophorella/Pyrgina group is robustly retained 224 (Figure 1) and forms a sister group relationship with Eutomopeas, Paropeas, Allopeas and 225 Leptinaria. The sister group relationship between Thyrophorella and Pyrgina is quite remarkable 226 because of the extreme morphological divergence. While Pyrgina possesses a typical subulinid 227 high spired dextral shell, Thyrophorella has a dorsally domed, almost discoid sinistral shell, 228 probably unique within the Achatinoidea. Proximal to the aperture, the body whorl of 
Thyrophorella forms a plate that flexes forward and establishes a close fitting seal to the aperture, a so-called 'false operculum'. This is a unique feature within the Gastropoda.

Tortaxis (as represented by the type species T. erectus) from Indochina and southern

232 China and Glessula (represented by G. ceylanica) from South Asia through parts of Myanmar,

233 Thailand, Vietnam, Sumatra, Java and Borneo (Pilsbry, 1906-1907) formed another group.

234 Conchologically, Tortaxis differs from Glessula in possessing a twisted apertural columella 235 rather than the truncated columella of Glessula. There is a need to include a wider range of 236 examples of what are currently understood to be Glessula in a molecular phylogeny and to 237 include the likely related genera Rishetia and Bacillum to establish their status and relationships.

It is clear from this study that while the Achatinoidea sensu Schileyko is a monophyletic

240 group, there is no support for recognising it as a distinct superfamily from the Subulinoidea

241 sensu Schileyko. Schileyko (1999) recognised four families within his Subulinoidea, the

242 Subulinidae, Glessulidae, Microtaenidae and Ferussaciidae. Micracteon was not available for

243 this study but from the known anatomy, particularly that of the jaw constructed of discrete plates,

244 its inclusion in the achatinoid clade requires confirmation (Bruggen and de Winter, 1995). It is

245 clear that the Ferussaciidae lies outside of the achatinid/subulinid clade. Glessulidae sensu

246 Schileyko as a monotypic family is not supported. Cryptazecinae Schileyko 1999 is excluded

247 from the Ferussaciidae as its monotypic genus, Cryptazeca, has been shown to be a member of

248 the non-achatinoid Cochlicopidae on anatomical criteria (Gomez and Angulo, 1987) and

249 molecular data (Madeira et al., 2010).

Within the Subulinidae, Schileyko (1999) recognised nine subfamilies: the Opeatinae, 251 Obeliscinae, Coeliaxinae, Subulininae, Petriolinae, Rishetinae, Tristaniinae, Rumininae and 
252 Perrieriinae. Within these subfamilies sensu Schileyko (1999) and on the basis of examined

253 species, the Ceoliaxinae, Subulininae, Petriolinae, Rishetinae and Rumininae are not supported

254 as subfamily groups; furthermore, with the exception of the Petriolinae, their monophyly was

255 strongly rejected by the SH Test. On the other hand, Tristaniinae has been shown not to be an

256 achatinoid, Tristania having been synonymised with Balea, a member of the Clausiliidae in the

257 non-achatinoid clade (Preece and Gittenberger, 2003). There is therefore a need to investigate the

258 morphological features of many anatomically undescribed species to correlate the molecular data

259 with morphological data. Other subfamilies that were not represented in this study (Obeliscinae,

260 Opeatinae, Perrieriinae and Tristaniinae) should likewise be surveyed to determine their validity

261 in light of the rejection of the monophyly of the Rishetiinae, Rumininae and Subulininae

262

\section{5. Acknowledgements}

264 This study was funded by a University of the Philippines PhD grant to IKF and a Leverhulme

265 Trust grant (F/00114U) to CMW. We would like to thank Cendrine Hudelot for her assistance

266 throughout the project.

267

268

269

\section{Literature cited}

Bouchet, P., Rocroi, J-P., 2005. Classification and nomenclator of the gastropod families. Malacologia 47(1-2), 1-397.

Cunningham, C.W., 1997. Can three incongruence tests predict when data should be combined? Mol. Biol. Evol. 14(7), 733-740.

Gomez, B.J., Angulo, E., 1987. On the systematic position of the genus Cryptazeca (Gastropoda: Pulmonata) Archiv für Molluskenkunde 118 (1-3), 57-62.

Goodacre, S.L., Wade, C.M. 2001 Molecular evolutionary relationships between partulid land snails of the Pacific. Proc. R. Soc. Lond. [Biol]. 268, 1-7.

Madeira, M.J., Elejalde, M.A., Chueca, LJ, Gomez, B., 2010. Phylogenetic position of the genus Cryptazeca and the family Azecidae within the system of the Stylommatophora. Malacologia 52(1), 163-168. 
Naggs, F., 1994. The reproductive anatomy of Paropeas achatinaceum and a new concept of Paropeas (Pulmonata: Achatinoidea: Subulinidae). J. Moll. Stud. 60, 175-191.

Nordsieck, H., 1986. The system of the Stylommatophora (Gastropoda), with special regard to the systematic position of the Clausiliidae, II. Importance of the shell and distribution. Arch. Molluskenkd. 117 (1-3), 93-116.

Pilsbry, H.A., 1906-1907. Achatinidae: Stenogyrinae and Coeliaxinae. In: Manual of Conchology. Structural and Systematic. With illustrations of the species. Second series: Pulmonata. Vol. 18. Philadelphia: Conchological Department of Academy of Natural Sciences.

Preece, R.C., Gittenberger, E., 2003. Systematics, distribution and ecology of Balea (=Tristania) (Pulmonata: Clausiliidae) in the islands of the Tristan-Gough Group. Journal of Molluscan Studies 69, 329-348.

Schileyko, A.A., 1999. Treatise on recent terrestrial pulmonate molluscs, Part 4: Draparnaudiidae, Caryodidae, Macrocyclidae, Acavidae, Clavatoridae, Dorcasiidae, Sculptariidae, Corillidae, Plectopylidae, Megalobulimidae, Strophocheilidae, Cerionidae, Achatinidae, Subulinidae, Glessulidae, Micractaeonidae, Ferussaciidae. Ruthenica, Moscow.

Schileyko, A.A., 2001. Treatise on recent terrestrial pulmonate molluscs, Part 7: Endodontidae, Thyrophorellidae, Charopidae. Ruthenica, Moscow.

Shimodaira, H., Hasegawa, M., 1999. Multiple comparisons of log likelihoods with applications to phylogenetic inference. Mol. Biol. Evol. 16, 1114-1116.

Solem, A., 1978. Classification of the Land Mollusca, in: Fretter, V., Peake, J. (Eds.), Pulmonates, Vol. 2A: Systematics, Evolution and Ecology. Academic Press, U.K., pp. 49-97.

Sutcharit, C., Naggs, F., Wade, C.M., Fontanilla, I., Panha, S., 2010. The new family Diapheridae, a new species of Diaphera albers from Thailand, and the position of the Diapheridae within a molecular phylogeny of the Streptaxoidea (Pulmonata: Stylommatophora). Zool. J. Linn. Soc. 160, 1-16.

Thiele, J., 1931. Handbuch der Systemmatischen Weichtierkunde. Zweiter Teil. Gastropoda II: Opisthobranchia (Hinterkiemer) III: Pulmonata (Lungenschnecken). Verlag von Gustav Fischer, Jena, pp. 377-778.

Tillier, S., 1989. Comparative morphology, phylogeny and classification of land snails and slugs (Gastropoda: Pulmonata: Stylommatophora). Malacologia 30(1-2), 1-303.

Van Bruggen, A.C., 1970. A contribution to the knowledge of non-marine Mollusca of Southwest Africa. Zool. Med. Leiden 45(4), 44-73.

Van Bruggen, A.C., de Winter, A.J., 1995. Notes on Micractaeon, a monotypic genus of African land snails (Gastropoda Pulmonata: Ferussaciidae?). Zoologische Mededelingen Leiden 69 (7): 79-92.

Vaught, K.C., 1989. A classification of the living mollusca. American Malacologists, Inc., Melbourne, FL.

Wade, C.M., Mordan, P.B., Clarke, B.C. 2001. A phylogeny of the land snails (Pulmonata: Gastropoda). Proc. R. Soc. Lond. [Biol]. 268, 413-422.

Wade, C.M., Mordan, P.B. and Naggs, F., 2006. Evolutionary relationships among the pulmonate land snails and slugs (Pulmonata, Stylommatophora). Biol. J. Linnean. Soc. $87,593-610$. 
325 Watson, H., 1928. The affinities of Cecilioides and Ferussacia, illustrating adaptive evolution. 326 J. Conchol. 18(8), 217-243.

327 Xia, X., Xie, Z., Salemi, M., Chen, L., Wang, Y., 2003. An index of substitution saturation and 328 its application. Mol. Phylogenet. Evol. 26, 1-7.

329 Zilch, A., 1959-1960. Euthyneura, in: Wenz, W. (Ed.) Handbuch der Palaozoologie, 6(2).

330 Gebruder Borntraeger, Berlin. 